University of Nebraska - Lincoln

DigitalCommons@University of Nebraska - Lincoln

6-1978

\title{
Adult Cestodes from the Coelomic Cavity of the Teid Lizard, Cnemidophorus sexlineatus
}

Wesley L. Shoop

Merck Laboratories

John J. Janovy Jr.

University of Nebraska - Lincoln, jjanovy1@unl.edu

Follow this and additional works at: https://digitalcommons.unl.edu/bioscijanovy

Part of the Parasitology Commons

Shoop, Wesley L. and Janovy, John J. Jr., "Adult Cestodes from the Coelomic Cavity of the Teid Lizard, Cnemidophorus sexlineatus" (1978). John Janovy Publications. 26.

https://digitalcommons.unl.edu/bioscijanovy/26

This Article is brought to you for free and open access by the Papers in the Biological Sciences at DigitalCommons@University of Nebraska - Lincoln. It has been accepted for inclusion in John Janovy Publications by an authorized administrator of DigitalCommons@University of Nebraska - Lincoln. 
J. Parasitol., 64(3), 1978, pp. 561-562

(c) American Society of Parasitologists 1978

\section{Adult Cestodes from the Coelomic Cavity of the Teid Lizard, Cnemidophorus sexlineatus}

In a survey of 64 Cnemidophorus sexlineatus, adult cestodes identified as Oochoristica bivitellobata with gravid proglottids were found in the coelomic cavity of two handcaught specimens at Cedar Point Biological Station, Ogallala, Nebraska, during June and July 1977. Two $O$. bivitellobata were found free in the coelom of a male lizard, whereas four were found in the coelom and one in the intestine of a female. No ruptures were found in the walls of the intestines of all lizards examined. In addition, $61 \mathrm{O}$. biviteilobata were found in the intestine of nine (14\%) of the C. sexlineatus with an average of 5.8 (1-18) worms per infected host.

The worms found in the coelom were active adults exhibiting no morphological anomalies and were structurally similar to those in the intestine. The average measurements (in micrometers unless otherwise indicated, with ranges in parentheses) of $O$. bivitellobata found in the coelom are within the limits of those given in the original description by Loewen (1940, Trans Am Microsc Soc 59: 511-518) and are, as follows: strobila $24.6(18-30) \mathrm{mm}$ long with a maximum of 21 proglottids (Figs. 1-3); scolex $360(300-510)$ wide and bearing four suckers each $140(130-160)$ in diameter, immature segments generally wider than long, mature segments 2,520 (2,200-2,840) long and $590(530-630)$ wide; gravid proglottids $6,350(5,900-7,400)$ long and $880 \quad(850-$ $1,040)$ wide; eggs with hexacanth larvae 48 (40-68) in diameter.

Carter and Etges (1973, J Parasitol 59: 1140-1141) described a cestode of the same genus, $O$. anolis, inhabiting the coelom of the lizard, Anolis carolinensis. These worms were active adults that were attached to the outer surface of the small intestine and liver. It is not known whether these matured in the coelom or migrated there as adults. Brooks and Mayes (1976, Trans Nebr Acad Sci 3: 20-21) reported a "crowding effect" in
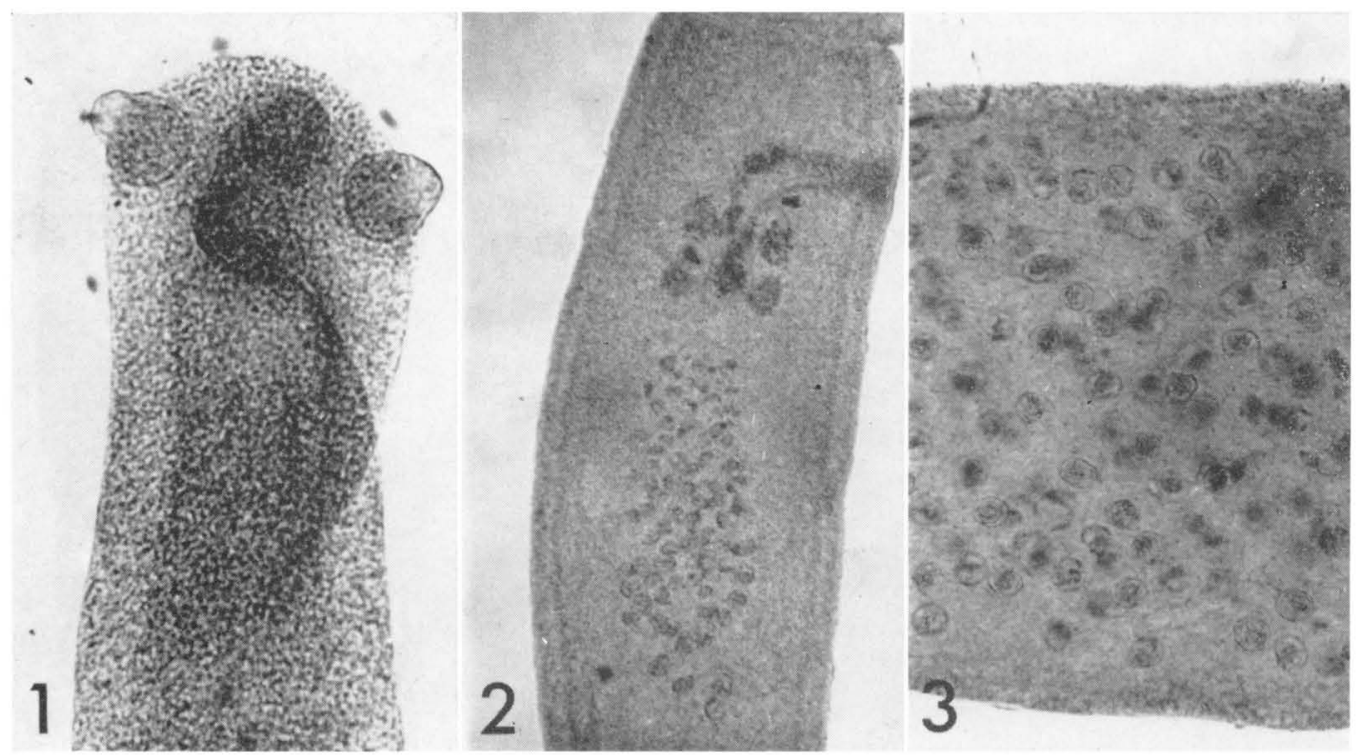

Figures 1-3. Oochoristica bivitellobata from the coelomic cavity of Cnemidophorus sexlineatus. 1. Scolex, 2. Mature proglottid. 3. Gravid proglottid. 
natural infections of $O$. bivitellobata in the intestine of $C$. sexlineatus, but they reported no extraintestinal worms.

Our findings show that only one intestinal worm was found in the two specimens of $C$. sexlineatus that had them in the coelom. It is not known whether coelomic worms are able to pass the hexacanth larvae to the outside or if they are reproductively isolated. Solomon (1974, Va J Sci 25: 182-184) reported that natural transmission of the mammalian parasite Capillaria hepatica can occur after the normal definitive host has been eaten by a rattlesnake. Parasite eggs were passed by the nematode in the snake's intestine. Cnemidophorus sexlineatus also is preyed upon by snakes and birds and it is possible that the same mode of larval dissemination is in operation here.

This is the first report of $O$. bivitellobata occurring extraintestinally. Active adults found in both the coelom and intestine suggest that both of these environments contain essential nutrients and osmotic characteristics that enable the worm to mature and carry out all differentiations leading to gravid proglottids. It is possible that the invasion of the coelom is accidental; however, these worms still possess an avenue of distribution by route of a predator.

Wesley L. Shoop, and J. Janovy, Jr., Cedar Point Biological Station, SLS, University of NebraskaLincoln, Lincoln, Nebraska 68588. 